\title{
A Belief Study on College English Teachers in the Cross-cultural Teaching under the World English
}

\author{
$\mathrm{Li} \mathrm{Na}^{1, \text { a }}$, Sun Lina ${ }^{2, b}$, Sun Xinhong ${ }^{3, c, *}$ \\ ${ }^{1,2,3}$ QILU Medical University, Zibo, Shandong, 255000 China

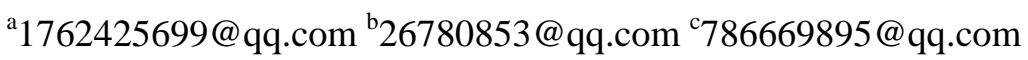

Keywords: World English; Cross-cultural Teaching; teacher belief; English education; college English teachers

\begin{abstract}
The development of world English makes contemporary English teaching generate the transformation of paradigm, while, cross-cultural teaching, as one of the important targets in English teaching, is also facing a new problem and challenge. It is impossible to meet students' cross-cultural exchange demands only by mastering British and American cultural knowledge. The belief and comprehension of college English teachers on cross-cultural teaching is the key to cross-cultural teaching. This study used the combination of the questionnaire and focus group interview to further study the belief of college English teachers on cross-cultural teaching. Contemporary college English teachers have sufficient cognition on the importance of cross-cultural teaching and started to value the comprehension and spread on the domestic culture, realizing the new challenge of world English development on cross-cultural teaching, but majorities of teachers still regard a language as a teaching center. Cross-cultural teaching gives priority to transmit knowledge and targets at exchange with people from native language culture countries. It should further explore cross-cultural teaching under the world English.
\end{abstract}

\section{Introduction}

Teacher belief is a topic concerned by scholars in recent years. "Teacher belief" refers to teachers' views and opinions on the teaching. The common studies on teacher belief get involved in the studies on teaching, learning, learners, subjects and role of teachers. Teacher belief is the core of teaching. The action of teachers in the classroom is determined by their desire. Under the new paradigm of English teaching brought by world English development and increasingly valuing background of Chinese college English education on cultivating students' cross-cultural exchange ability, to understand the cross-cultural teaching belief of college English teachers is to ensure the key of cross-cultural teaching.

2. The belief concept of college English teachers on cross-cultural teaching under the world English

\subsection{Connotations in cross-cultural continuousness of English teachers}

The cross-cultural continuousness of English teachers refers to English teachers' sensitive cognition on cultural factors in the cross-cultural exchange. According to the sensitivity to similarities and dissimilarities of different culture and common culture and utilization of foreign language, they adjust their language comprehension and consciousness of language production.

\subsection{Dimension in cross-cultural consciousness of English teachers}

Cross-cultural consciousness is the cultural consciousness on the cross-cultural exchange process. On the one hand, it belongs to the object consciousness - the consciousness with the object of culture. On the other hand, it is the self-consciousness of human, namely in the cultural exchange, people inspect on themselves from another culture. As a result, the author thinks that the dimension of English teachers' cross-cultural consciousness should get involved in two parts: 
self-consciousness of English teachers and cultural consciousness of English teachers. The self-consciousness of English teachers means that English teachers constantly inspect on their behaviors in the cross-cultural exchange process. Here, "cross-cultural exchange" includes the face-to-face exchange between English teachers and foreigners and also contains the cultural exchange between teachers and students in the classroom teaching. The cultural consciousness of English teachers refer to English teachers' cognition and comprehension on the cultural value affecting self-thinking, including cultural cognitive consciousness, cultural comprehensive consciousness and cultural practice consciousness. The cultural cognitive consciousness refers to the cognition and comprehension on foreign cultural knowledge. The cultural comprehensive consciousness refers to the attitude towards the foreign culture, showing that in cross-cultural exchange, English teachers can temporarily stop doubting foreign culture and trust self-culture. It is necessary to comprehend and respect foreign culture and exchange with the opposite side with an open attitude from the perspective of opposite standpoint. The cultural practice consciousness means that in the English teaching process, it can suitably conduct cultural guide, including cultural knowledge explanation, cultural attitude penetration and cultural ability improvement.

\subsection{The theoretical assumption of English teachers' cross-cultural consciousness development stage}

After defining the connotations and dimensions of cross-cultural consciousness, the author conducts the theoretical assumption on English teachers' cross-cultural consciousness development stage and describes the model status of English teachers' cross-cultural consciousness in each stage, shown in Table 1.

Table 1 Three Stages of English Teachers' Cross-Cultural Consciousness

\begin{tabular}{|c|c|c|c|c|c|}
\hline \multirow{5}{*}{$\begin{array}{l}\text { English } \\
\text { teachers } \\
\text { Cross-cultural } \\
\text { consciousness }\end{array}$} & \multirow{2}{*}{$\begin{array}{c}\text { Three stages of } \\
\text { culture } \\
\text { development }\end{array}$} & \multicolumn{4}{|c|}{ Performance of English teachers' cross-cultural consciousness } \\
\hline & & $\begin{array}{l}\text { Cultural } \\
\text { cognitive } \\
\text { consciousness } \\
\end{array}$ & $\begin{array}{l}\text { Cultural } \\
\text { comprehensive } \\
\text { consciousness } \\
\end{array}$ & $\begin{array}{l}\text { Cultural } \\
\text { practice } \\
\text { consciousness }\end{array}$ & Self-consciousness \\
\hline & $\begin{array}{l}\text { Cultural } \\
\text { acceptance } \\
\text { stage }\end{array}$ & $\begin{array}{l}\text { Familiar with } \\
\text { cultural } \\
\text { connotations of } \\
\text { English words } \\
\text { and understand } \\
\text { the cultural } \\
\text { differences of } \\
\text { words }\end{array}$ & $\begin{array}{l}\text { Realize cultural } \\
\text { existence in } \\
\text { language } \\
\text { teaching }\end{array}$ & $\begin{array}{l}\text { Realize } \\
\text { importance of } \\
\text { cultural } \\
\text { knowledge and } \\
\text { explain foreign } \\
\text { culture }\end{array}$ & $\begin{array}{l}\text { Realize } \\
\text { self-behavior in } \\
\text { exchange, but can't } \\
\text { correctly adjust the } \\
\text { relationship between } \\
\text { language and culture }\end{array}$ \\
\hline & $\begin{array}{c}\text { Cultural } \\
\text { adaption stage }\end{array}$ & $\begin{array}{l}\text { Realize } \\
\text { behavioral } \\
\text { differences and } \\
\text { daily exchange } \\
\text { differences and } \\
\text { comprehend } \\
\text { foreign culture } \\
\text { in theory }\end{array}$ & $\begin{array}{l}\text { Comprehend and } \\
\text { respect foreign } \\
\text { culture and } \\
\text { absorb and select } \\
\text { with a choice } \\
\text { based on it }\end{array}$ & $\begin{array}{l}\text { Change the } \\
\text { teaching mode } \\
\text { and introduce } \\
\text { the cultural } \\
\text { comparison to } \\
\text { do cultural } \\
\text { teaching }\end{array}$ & $\begin{array}{l}\text { Adjust self-behavior } \\
\text { in exchange in line } \\
\text { with situations }\end{array}$ \\
\hline & $\begin{array}{c}\text { Cultural } \\
\text { internalization } \\
\text { stage }\end{array}$ & $\begin{array}{l}\text { Familiar with } \\
\text { the thinking } \\
\text { mode of } \\
\text { foreign culture, } \\
\text { value and } \\
\text { social } \\
\text { relationship }\end{array}$ & $\begin{array}{l}\text { On the basis of } \\
\text { comprehension } \\
\text { and respect, } \\
\text { consider for } \\
\text { other opposite } \\
\text { considerably }\end{array}$ & $\begin{array}{l}\text { Guide students } \\
\text { to experience } \\
\text { foreign culture } \\
\text { by watching a } \\
\text { video, directly } \\
\text { contacting with } \\
\text { foreigners and } \\
\text { holding } \\
\text { relevant } \\
\text { activities }\end{array}$ & $\begin{array}{l}\text { Have the empathic } \\
\text { ability, change } \\
\text { self-behavior and act } \\
\text { as multiple roles to } \\
\text { adapt to exchange } \\
\text { situation }\end{array}$ \\
\hline
\end{tabular}




\section{Belief study analysis of college English teachers on cross-cultural teaching under the world English}

\subsection{The difference analysis of classroom cross-cultural teaching between different genders}

Genders almost have no difference in four dimensions of the classroom cross-cultural teaching, but as surfing the internet to brose English cultural webpage, the chi-square test shows that $\mathrm{p}$ of likelihood ratio statistics is equal to 0.012 , which is less than 0.05 . The overall distribution has the significant difference. Many and relative much more for male teachers to browse webpage account for $62.5 \%$. Proportion of seldom in female teachers accounts for 68.8\%. (Table2) Male teachers are better than female teachers to use the internet to absorb cultural knowledge of English. 87.5\% of teachers are interested in English national culture and increase knowledge contents through the English cultural program.

Table 2 The English Cultural Webpage Comparison of English Teachers about Different Genders

\begin{tabular}{|c|c|c|c|c|}
\hline \multirow{2}{*}{ Projects } & \multirow{2}{*}{ Items } & \multicolumn{3}{|c|}{ Genders } \\
\hline & & Male(8) & Female(16) & Total \\
\hline \multirow{8}{*}{$\begin{array}{l}\text { Browse English cultural } \\
\text { webpage }\end{array}$} & \multirow{2}{*}{ Many } & 3 & 0 & 3 \\
\hline & & $37.5 \%$ & $0.0 \%$ & $12.5 \%$ \\
\hline & \multirow{2}{*}{$\begin{array}{l}\text { Relatively } \\
\text { much more }\end{array}$} & 2 & 5 & 7 \\
\hline & & $25.0 \%$ & $31.3 \%$ & $29.2 \%$ \\
\hline & \multirow{2}{*}{ Less } & 2 & 11 & 13 \\
\hline & & $25.0 \%$ & $68.8 \%$ & $54.2 \%$ \\
\hline & \multirow{2}{*}{ Basically no } & 1 & 0 & 1 \\
\hline & & $12.5 \%$ & $0.0 \%$ & $4.2 \%$ \\
\hline
\end{tabular}

\subsection{Difference analysis of the classroom cross-cultural teaching in different ages}

One of approaches for different ages to transport English cultural knowledge is film. Through the chi-square test, $\mathrm{p}$ of likelihood ratio statistics is equal to 0.025 , which is less than 0.05 . The overall distribution has the significant difference. Teachers in $20-30$ years old account for $83.3 \%$ to use films for spreading English cultural knowledge, while teachers in 31-40 years old occupy 36.4\%. No teachers in 41-50 years old select it (Table 4). Younger teachers under 30 years old prefer to use films to do cross-cultural teaching in English classroom, take full advantage of modern education resources in teaching, and apply multiple teaching modes. Young teachers are energetic and prefer to accept the teaching philosophy of new curriculum reform, become familiar with the modern education technology, provide the favorable language study conditions for students, and promote cross-cultural teaching in English classroom.

Table 3 The Film Comparison of College English Teachers in Different Ages

\begin{tabular}{|c|c|c|c|c|c|}
\hline \multirow{3}{*}{ Projects } & \multirow{3}{*}{ Items } & \multicolumn{3}{|c|}{ Ages } & \multirow{2}{*}{ Total } \\
\cline { 3 - 6 } & & $20-30$ years old(12) & $31-40$ years old(11) & $41-50$ years old(1) & \\
\hline \multirow{3}{*}{ Films } & No & 2 & 7 & 1 & 10 \\
\cline { 3 - 6 } & & $16.7 \%$ & $63.6 \%$ & $100.0 \%$ & $41.7 \%$ \\
\cline { 3 - 6 } & \multirow{2}{*}{ Yes } & 10 & 4 & 0 & 14 \\
\cline { 3 - 6 } & & $83.3 \%$ & $36.4 \%$ & $0.0 \%$ & $58.3 \%$ \\
\hline
\end{tabular}




\subsection{Belief improvement of cross-cultural teaching}

1) Correctly comprehend and implement classroom cross-cultural teaching: teachers should have the correct comprehension and cognition on the classroom cross-cultural teaching, constantly improve the subject knowledge quality, use multiple channels to gain the latest information in social cultural life of British and American countries, and integrate the information into their teaching practice.

2) Have the deep comprehension on world English development from policy making

From the perspective of policy making, teachers should have the deep understanding on teaching requirements under the world English development and formulate the language planning policy conforming to the era development. The publication of College English Teaching Guide(2017) embodies the importance of cross-cultural exchange ability cultivation of policy makers, but the effective implementation of this programmatic documents should further improve teachers' belief in new policy and reinforce teachers' comprehension on new policy. From the perspective of teaching training, it is necessary to improve teachers' comprehension on cross-cultural teaching development under the globalization and world English development tendency, cultivate teachers' global cultural consciousness and timely provide the latest development tendency in international cross-cultural teaching field for teachers. In college teaching management, it suggests that the time of classroom cross-cultural teaching should be increased in the teaching program requirements. In teaching resources, it is necessary to integrate into the worldwide diversified cultural materials. In language testing, it is necessary to increase evaluation on students' cross-cultural consciousness and ability.

\section{Conclusions}

Facing to the overall tendency of globalization and world English development, to improve teachers' comprehension and belief in cross-cultural teaching, help teachers to gain the cross-cultural mode with strong practice and operability conforming to the new paradigm and specific practice method is the topic to be reflected by policy makers, teacher trainees and teachers.

\section{Acknowledgements}

Project number: 11CWZZ23 project name: English culture teaching strategy in higher vocational colleges. Project fund: Shandong Provincial Social Science Planning and management office.

Fund Project: Shandong social science planning and management office, project name: Research on the effective way of College Students' Ethos Education under the background of globalization. Project number: 15CSZJ31

\section{References}

[1] Wang Hongyu, the Exploration on Chinese Cultural Infiltration in College English Teaching[J], Journal of Jinan Professional School, 2015(06): 86-88.

[2] Yang Jixing, the Importance of Cultural Teaching in College English Teaching[J], English Teachers, 2016, 16(03): 107-109.

[3] Duan Ran, the Status, Problems and Countermeasures of Cross-cultural Education in College English Teaching[J], Talent Resource Development, 2016(06): 176-177

[4] Liang Jing, the College English Teaching Mode Study under the Cross-cultural Perspective[J], Chinese Market, 2016(23): 208-209.

[5] Yang Junru, the Empirical Study Review on English Teachers and Cross-cultural Foreign Teaching[J], Overseas English, 2018(01): 74-75+77 